\title{
Teachers' Perception on Blended-Learning Model in Teaching English at State Vocational School Assisted by Edmodo
}

\author{
Rini Ekayati ${ }^{1}$ \\ ${ }^{1}$ University of Muhammadiyah Sumatera Utara, Medan, Indonesia, ه(email), riniekayati@umsu.ac.id.
}

\begin{abstract}
This research is aimed to describe teachers' perception on blended-learning model in teaching English at State Vocational School. Descriptive qualitative method was used in this study in order to examine how teachers perceived the implementation of blended-learning model assisted by Edmodo in teaching English subject. Questioners and interview were used as source of data administrated to 10(ten) respondents of this research. The respondents were English teachers at two State Vocational Schools of Deli Serdang districts, namely SMK Negeri 1 Percut and SMK Negeri Beringin. Based on the questionnaire and interview, the result showed that blended-learning model assisted by Edmodo could help to resolve the problems and difficulties in teaching English in the class. Teachers could facilitate students with a more interactive learning environment. This might affect the students' learning outcomes. So, the English teachers had positive perception of the blended-learning model assisted by Edmodo.
\end{abstract}

Keywords: Teaching English, Blended-learning Model, Edmodo, Teachers' Perception

\section{INTRODUCTION}

Until late of 90s, the implementation of learning was arranged and concentrated on active-students-based curriculum. Then, in the 2000 s there was transformation of learning model by the implementation of competencybased curriculum in education. During 2000s as well, there is transformation of teaching and learning model which leads to a new dimension of education. This transformation was utilized by the Information Communication Technology (ITC). The ITC nowday has developed into a new style of human interaction, by means that the interaction is not limited by space and time. In education, there is also movement in term of how teachers and students involve in a teaching and learning environment by the influences of ITC development. ITC becomes a necessary need to provide information about sciences that can be obtained faster and more effective. By this situation, teachers are challenged in upgrading themselves to be able to adopt the ITC usage in the learning and teaching which can be conducted not only in a real classroom, but also in a virtual classroom in an elearning model. It is confirmed by the government policy No. 50/2000 about the utilization of ITC in education which is known as e-education. (Usman, 2017).

The utilization of e-learning model is a great movement in education, but still there are challenges in its implementation. By its definition, e-learning is an instruction which is delivered on digital equipments that is intended to support learning. The desktop or laptop computers to tablets to smart phones are the delivery hardware supported the e-learning model to support individual learning or organizational performance goals. (Clark, R. C., \& Mayer, R. E., 2016). E-learning model is not directly accepted by teachers around the globe. There is still discussion about whether e-learning model should be fully conducted or partly in the learning and teaching activities nowdays, since for some teachers to meet students in a classroom is also important.

These two points of view lead to the emergence of another model of teaching and learning which is known as blended learning model. Blended learning has become a buzzword in many educational environments in recent years, usually referring to courses that employ a mix of face-to-face and online learning. (Tomlinson, B., \& Whittaker, C.,2013) (Bonk \& Gra $\neg$ ham, 2012). The blended-learning model is a combination of e-learning and traditional class systems. With this system it will accommodate elements of e-learning such as simulations, virtual laboratories, and online discussions into face-toface learning in class. Learning activities can be improved using blended-learning, including collaboration and discussion, online quizzes and assignments, online inquiry and exploration, such as individual activities such as ejournals, blogs or e-portfolios. Face-to-face activities can also be applied in a blended-learning system, such as tutorials, lab work in the laboratory and project work. (Ekayati, R., 2019). To conclude, that e-learning is learning that uses ICT in order to transform the learning process happened between educators and students. The main purpose of using ITC in this situation is to improve 
efficiency and effectiveness, transparency, and learning accountability, while blended learning itself is a learning method that combines e-learning systems with conventional methods or face-to-face. (Murtiyasa, 2012).

In the implementation of blended-model in teaching and learning, teachers can be facilitates by an online application to support the online session during the class activity. One of it is Edmodo. Edmodo is a blended learning platform designed by O'Hara and Borg in 2008 and is now available at www.edmodo.com. It is used by many educational institutions all over the world for its attracting features, like user-friendliness, free and secure online environment, the top teaching and learning websites developing innovation, and creativity literacy learning and communicating. (Purnawarman. et. all, 2016). On the other hand, Edmodo, as one of the learning management system which is friendly use and free to access, is one of the learning tolls that can provide teachers with an application that can be utilized with the e-learning model. So, the collaboration of the e-learning model and Edmodo can be use to facilitate or to solve teachers and students problems in teaching and learning English. Therefore, there is no doubt about how Edmodo facilitates students' learning experience to take place. According to Zwang (2010), Edmodo is a social networking-based educational site in which there are various content for education. Teachers/lecturers can post learning materials, share links and videos, project assignments, and notify student grades directly. In addition, Edmodo can store and share all digital content including blogs, links, images, videos, documents and presentations. So, Edmodo is a social media that can connect teachers/lecturers with students / students in a learning group where teachers / lecturers can send some learning material, agendas, and assignments, as well as direct assessment.

When compared to other learning management system like moodle platform, Edmodo is easier to use. The features contained in Edmodo application have similarities with one of the social media that is currently widely used by the public, Facebook. Although it is easy to be used, Edmodo also guarantees the confidentiality of its members with special code facilities for each virtual class. In addition, another feature of Edmodo is the ease of access and application. Edmodo can be accessed for free, can be applied starting from one class, one school, even between schools. It can also be used not only by teachers and students, but can also involve students' parents.

Related to English Language Teaching (ELT), blended learning model which is assisted by Edmodo as an online platform in learning has been applied by teachers in class activities. Previous study showed that blended approach can be adopted in low-resource environments with large numbers of students, increased study hours for students and the promotion of independent learning, improving students' access to learning and offering them greater flexibility. (Tomlinson, B., \& Whittaker, C.,2013). The problem of English teaching and learning English may vary depends on some factors, and also the study level of the students. In Indonesia context, from year to year the success of learning English for high school level, including the vocational school, is still not satisfying for parents, professionals, and lecturers when students start college. This can be caused by several factors, including learning methods that are not varied or boring. Learning methods chosen by teachers tend to be conventional, there is no visible effort to innovate and create using learning methods that are more in line with the development of the current era. (Kastaredja (2008). Moreover, this condition is much worse by the lack of effort done by English teachers to start to utilize ITC and its component like laptops and the internet which can influence the success of the learning process itself. Even though, there are many schools provide free internet facilities (Wi-Fi), still few teachers utilize this facility to support their teaching activity in the class. (M. Arifin and Rini Ekayati: 2016). It seems that teachers need to be well informed about the fascinating growth in education support by the ITC development. These features may be a useful insight solution for teachers who face problems in teaching English in the class. Teachers' perception of that transformation of new model of teaching will be valuable information, as well. Therefore, this study is aimed to investigate teachers' perception on blended learning model in teaching English at State Vocational School assisted with Edmodo. This paper will discuss how English teachers perceive the blended learning model assisted with Edmodo in teaching and learning activity, along with the possible benefit and challenges.

\section{METHOD}

The qualitative research methodology was applied in this study. By using purposive sampling technique, ten (10) respondents who were English teachers from two State Vocational School were selected. The English teachers were state civil teacher and non-state civil teacher who had teaching English at the state vocational school around 3-11 years. Besides, the English teachers chosen based on the teachers' experience in teaching English at State Vocational School with the help of ICT tools in the class. It was necessary to figure out how familiar ICT for teachers.

There some steps administrated in collecting the data. Data collected in this study were qualitative data in the form of questionnaires, observation, and direct interview. Questionnaires and direct interview were administrated to obtain related information on the English teachers' perception on blended learning method assisted by Edmodo. The questions were modified related to the factors that affected the blended learning method assisted by Edmodo that might be based on the teachers' experiences and knowledge. Moreover, teachers' perception on blended learning model assisted by Edmodo was strengthened by the observation conducted during blended leaning model in teaching and learning activity in the class, and during this session questions were asked to the English teachers. Further, the data collected had been clarified by using the 3C (Connection, Confident, and Content) strategies (Tomlinson, B., \& Whittaker, C., 2013), and Yusof's conceptual model when the blended 
learning model assisted by Edmodo was implemented in the class activity. (Yusof \& Hin, 2009). To validate the data, triangulation technique was used. By this technique, the data was determined in accordance with the convergence of several data sources or several data collection. (Moleong, 2007). The collected data were analyzed using qualitative descriptive methods through data collection, data reduction (data reduction), data display (datadisplay), and conclusion drawing. (Sugiyono: 2010).

\section{RESULT AND DISCUSSION}

The overall data collected from questionnaires, direct interview, and observation was determined by $3 \mathrm{C}$ strategies and the conceptual model. Data obtained were dominated by the English teachers' perception on how the blended learning model assisted by Edmodo should be implied in teaching English subject, and also factors that affected the process of the implementation of blended learning model assisted by Edmodo in teaching English subject at the vocational school.

\section{Connection}

In connection strategies, the network connectivity became the major concern based on the English teachers' perception, besides other element like the facilities and accessibility. This might be because the school where the respondents teach right now already provided facilities that make it possible for the ICT learning activity. The one problem that might affect the blended learning model assisted by Edmodo is the students' connection. Teachers' perception on this point was in two side option. First, it was teachers or school that should provide the connection for students or the students themselves to provide it. It then leaded to the accessibility of the Edmodo application. Since it was free platform, schools or teachers should not pay for it, but still connection was needed to access it.

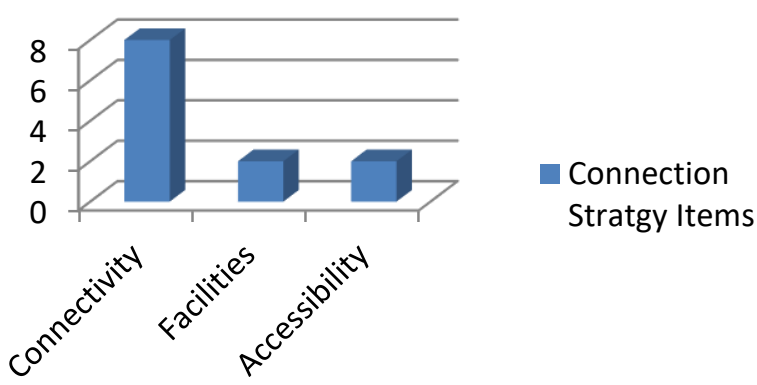

Figure 1. Distribution of Connection Strategy Items

Figure 1 showed that the connectivity item got the higher consideration based on the English teachers' perception of the blended model assisted by Edmodo application, followed by facilities and accessibility.

\section{Confidence}

Related to the confidence strategy, teachers' habit using ICT equipment in teaching, skills (including teachers' skill in using ICT facilities), creativity in designing class activity, experience and knowledge became the factors that affected English teachers' confidence in implementing the blended learning model assisted by Edmodo. For some teacher, who were got used to with ICT operation in teaching, blended learning model was not a new one for them. It related to their experience and confidence as well. ICT also gave challenge for the teacher to creatively design their class activity in order to accommodate the benefit of ICT usage. Moreover, the facilitate in the Edmodo application made it possible for teachers to design the class activity, like task or examination. This affected the teachers' confidence in teaching English in the class by using blended learning model assisted by Edmomo, besides their background knowledge of English subject, and ICT as well. By utilizing the ICT learning by the blended learning model assisted by Edmodo, teachers might feel more confidence to handle the class, and it affected the condition of learning that was more conducive and effective. Personally, teachers were more comfortable in delivering the material in the class.

The distribution of Confidence Strategy items were shown below.

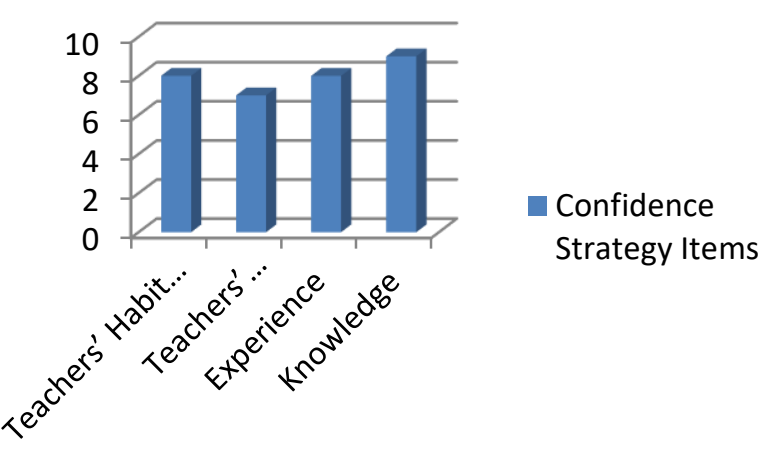

Figure 2. Distribution of Confidence Strategy Items

\section{Content}

According to the English teachers' perception, the learning outcome, learning time or Jam Pelajaran (JP), English subject material, class assessment, and students' daily or week task needed to be considered in content item of designing strategies in implementing blended learning model assisted by Edmodo in the class. Regarding the learning time, at the vocational school there were $3 \mathrm{JP}$ for the English subject in a week. Teachers perceived that the proper contribution between online class with face-to-face class in blended learning model was that 2 JP for online class and $1 \mathrm{JP}$ for face-to-face. Edmodo as the assisted median in the blended learning model here could help teacher in providing class assessment like, giving online task to the students that could be uploaded through 
students' Edmodo account. It could be the students' daily and weekly task. Moreover, the teachers perceive that this situation might help teachers in managing the learning time, and for students it might help them to do their task not only in the real class, but also in the virtual class.

Below, the diagram showed the distribution of items related to the content strategy of the $3 \mathrm{C}$ strategy.

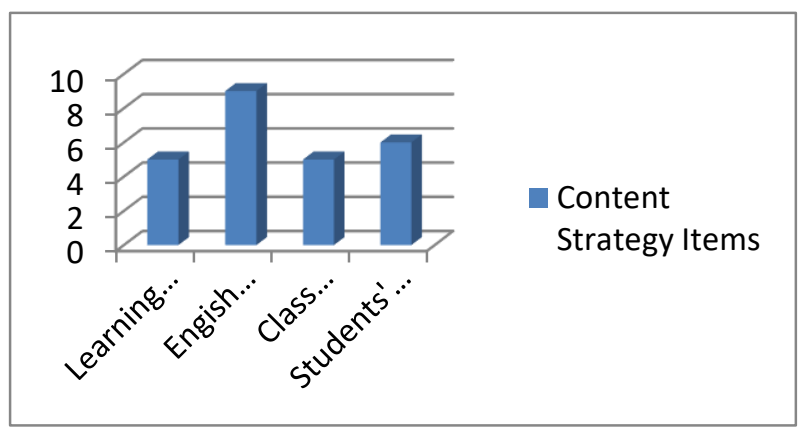

Figure 3. Distribution of Content Strategy Items

The above diagram showed that there were five (5) respondents who considered the learning time to be one factors in content strategy, nine (9) respondents considered English subject material, five (5) respondents considered class assessment, and six (6) respondents consider the students' daily and weekly task as the other factors in content strategy. By this data, it showed that the English subject material became the major consideration in content strategy in the implementation of blended learning model assisted by Edmodo.

\section{CONCLUSION}

To conclude, the English teachers' perception on the blended learning model assisted by Edmodo,based on the questionnaire and interview, the result showed that blended-learning model assisted by Edmodo could help to resolve the problems and difficulties in teaching English in the class. Teachers could facilitate students with a more interactive learning environment. Based on the $3 \mathrm{C}$ strategy, the teachers' perception of the blended model assisted by Edmodo showed that the major concern were related to the connectivity access, the teachers' knowledge and habit in using ICT in learning activity, and the English material. Moreover, teachers needed to know about the blended learning model assisted by Edmodo, learnt about it, then utilized it in teaching activity in the classroom.

\section{ACKNOWLEDGMENTS}

This article was the additional output of the research that had been conducted previously. Here, I would like to thank you University of Muhammadiyah Sumatera Utara (UMSU) that has funded and support this research through Research and Public Service Unit under the Internal Research Program for the lecturer at UMSU. To all the English teachers from two (2) vocational schools at Deli Serdang region, thank you for the time and cooperation, and to all those who had assisted in the completion of this research that cannot be mention here one by one.

\section{REFERENCES}

[1] Arifin, M. (2017). IBM Pelatihan Mendisain Media Pembelajaran E-learning dengan Applikasi Edmodo Bagi Kelompok Guru di SMK Negeri Deli Serdang. Jurnal prodikmas Hasil Pengabdian Kepada Masyarakat, 1(01).

[2] Bonk, C. J., \& Graham, C. R. (2012). The handbook of blended learning: Global perspectives, local designs. San Francisco, CA: Pfeiffer.

[3] Clark, R. C., \& Mayer, R. E. (2016). E-learning and the science of instruction: Proven guidelines for consumers and designers of multimedia learning. John Wiley \& Sons.

[4] Ekayati, R. (2019). Study of Blended-Learning Method Assisted By Edmodo in Teaching English at State Vocational School in Deli Serdang. Budapest International Research and Critics in Linguistics and Education (BirLE) Journal, 2(3), 18-26.

[5] Horn, M., \& Staker, H. (2011). The rise of $K-12$ blended learning. International Association for $\mathrm{K}$ 12 Online Learning. Retrieved from http://www.innosightinstitute.org/innosight/wpcontent/uploads/2011/01/The- $\quad$ Rise-of-K-12Blended-Learning.pdf

[6] Moleong, L. 1997. Metodologi Penelitian Kualitatif. Bandung; PT Remaja Rosdakarya.

[7] Murtiyasa, B. (2012). Pemanfaatan Teknologi Informatika dan Komunikasi untuk meningkatkan Kualitas Pembelajaran Matematika. Surakarta: FKIP Univ. Muhammadiyah Surakarta. (on-Line) tersedia: am\%20pendidikan/TIK inEduMath.pdf.

[8] Purnawarman, P., Susilawati, S., \& Sundayana, W. (2016). The use of Edmodo in teaching writing in a blended learning setting. Indonesian Journal of Applied Linguistics, 5(2), 242-252.

[9] Sugiyono. (2015). Metode Penelitian Kuantitatif Kualitatif $R \& B$. Bandung: Aflabeta.

[10] Tomlinson, B., \& Whittaker, C. (2013). Blended learning in English language teaching. London: British Council.

[11]Usman, U. (2017). Dinamika Pembelajaran Berbasis Teknologi Informasi Pada Lembaga Pendidikan Tinggi. Jurnal Jurnalisa, 3(1).

[12] Yusof, A. M., Daniel, E. G. S., Low, W. Y., \& Ab, K. (2011). Teachers' perceptions on the blended learning environment for special needs learners in Malaysia: a case study'. In 2nd International Conference on Education and Management Technology, Shanghai, China.

[13] Yusof, A. M., \& Hin, H. S. (2009). eSekolah: The Usability of School Management Application in Primary Schools from Malaysia's Perspective. 
Paper presented at the 13th APEID International Conference, Hangzhou, Republic of China.

[14]Zwang, J. 2010. Edmodo: A free, secure social networking site for schools. http://www.eschoolnews.com/2010/12/15/edmodoa-free-secure-social-networkingsite-for-schools/, diakses 15 Oktober 2017. 